\title{
Energy metabolism of follicular environment during oocyte growth and maturation
}

\author{
Ewelina WARZYCH ${ }^{1)}$ and Paulina LIPINSKA ${ }^{1)}$ \\ ${ }^{1)}$ Department of Genetics and Animal Breeding, Poznan University of Life Sciences, Poznan 60-637, Poland
}

\begin{abstract}
Oocyte quality is affected by many factors, among which the environment of growth and maturation seems to be crucial. Studies show that well balanced oocyte energy metabolism has a significant impact on several elements of cytoplasmic and nuclear maturation as well as further embryo developmental competence. Therefore homeostasis between metabolism of glucose and fatty acids in the oocyte is being widely described nowadays. This review aims to discuss the follicular (in vivo) or maturation media (in vitro) environments with regard to glucose and fatty acid metabolism, as the main sources of the energy for the oocyte. A great emphasis is given on the balance between those two metabolic pathways and its further impact on female fertility.
\end{abstract}

Key words: Energetic homeostasis, Fatty acids, Glucose, Oocyte maturation, Oocyte quality

(J. Reprod. Dev. 66: 1-7, 2020)

\section{Energy Metabolism in the Female Organism}

Oocyte is the largest mammalian cell. Its development is more energy consuming in comparison to the somatic cells. However as a benefit, this large cell can provide enough substrates for energy production necessary for the initial days of embryo development. Therefore, well balanced energy metabolism of the oocyte will most definitely impact further embryo development and quality. The question arises, what "well balanced metabolism" means and how it can be measured and predicted.

The most common sources of energy for the mammalian cell are either glucose or fatty acids. They enter the cytosol of the cell and convert into acetyl-CoA, which is finally oxidized to ATP for energy production. Fatty acids are utilized via $\beta$-oxidation (FAO), whereas glucose is the substrate mainly for glycolysis, pentose phosphate pathway (PPP) and hexosamine pathway. Oxidation of both substrates takes place in mitochondria. Fatty acids allow to obtain substantially higher amount of energy when compared to glucose.

The described processes of energy production are precisely controlled, but also flexible, depending on cell's environmental conditions. The main causes of metabolic fluctuations arise from the availability of enzymes, substrates and the catalytic activity of the enzymes. The limited substrate availability may lead the cell not to choose the preferable energy metabolism pathway, but to utilize the most available at the moment. On the other hand, free access to the specific substrate for energy metabolism should limit

Received: August 27, 2019

Accepted: November 8, 2019

Advanced Epub: December 2, 2019

(C)2020 by the Society for Reproduction and Development

Correspondence: E Warzych (e-mail: ewelina.warzych@up.poznan.pl)

This is an open-access article distributed under the terms of the Creative Commons Attribution Non-Commercial No Derivatives (by-nc-nd) License. (CC-BY-NC-ND 4.0: https://creativecommons.org/licenses/by-nc-nd/4.0/) other options of energy production, as a reverse negative effect. Such relations have been well described in the literature. Several experiments summarized by Randle [1] confirm that within the human body, fatty acids provision promotes fatty acid oxidation and inhibits glucose oxidation simultaneously. Other studies show that glucose provision promotes glucose oxidation, inhibiting fatty acid oxidation. This phenomenon has been described in various tissues like heart muscle, adipocytes, liver, etc. Thus, the question arises whether such attempts to balance the energy are also observed in oocytes, especially during their growth and maturation, and what is its further impact on embryo quality.

Both for animals and human, female fertility is a complex trait combining numerous processes, such as nutrition, physiological status etc. All these parameters may influence not only the global metabolic processes within the female, but also affect oocyte and embryo quality via the maternal disorders of lipid or glucose metabolism. In human, overweight or obese women have reduced pregnancy and live-birth rates and significantly reduced oocyte quality (reviewed by [2]). With regard to cows, there is an observed phenomenon called negative energy balance. It is a high requirement for energy due to rapid growth of the fetus in the last weeks of pregnancy and increasing milk production after calving. As a consequence, it is characterized by alternations in plasma metabolite levels, including increased circulation of non-estrified fatty acids (NEFA) and further modifications of follicular fluid composition (reviewed by [3]). A substantial influence of NEFA concentration in bovine follicular fluid or in vitro oocyte maturation media was observed to impact the oocyte quality, with a key role of cumulus cells in protection against lipotoxicity $[4,5]$. Cows with fertility problems have also significantly lower circulating glucose concentrations compared to cows with normal fertility [6]. Therefore it is suggested that an optimal physiological concentration of glucose and fatty acids is crucial for proper oocyte development and maturation, as well as for the establishment of the nascent embryo's developmental potential. 
In the follicular fluid a complex set of nutrients during follicular development is collected in order to support the growth and development of cumulus-oocyte complex. Since both glucose and fatty acids are detected, one may assume that both these substrates are essential to support oocytes competence acquisition. The question however arises what is the proper balance between glucose and fatty acids to obtain the most optimal effect of oocyte quality establishments. In the process of oocyte quality determination, all the elements of follicular environment are involved however follicular fluid and follicular cells are described as being the most crucial for oocyte proper development [7]. In the following review, the follicular environment will be discussed with regard to glucose and fatty acids metabolism and their metabolic balance with the further impact on the wider concept of female fertility.

\section{Glucose Metabolism within the Follicular Environment}

Most mammalian cells use glucose predominantly for ATP synthesis. Also cumulus-oocyte-complexes base their energy metabolism on glucose and mature cumulus oocyte complexes (COCs) consume two-fold more glucose and pyruvate than the immature ones [8]. It indicates high energy demand of the changes that take place during the process of preparing the oocyte for fertilization. Surprisingly, the oocyte itself has a low capacity for glucose metabolism due to low phosphofructokinase activity [9]. Besides, due to its hydrophilic nature, glucose cannot diffuse across the plasma membrane but it is transported through nutrient transporters of solute carrier family. Therefore oocytes of most mammalian species must rely on metabolism of cumulus cells, which due to additional GLUT transporters with high affinity to the substrate, absorb glucose either form follicular fluid (in vivo) or maturation medium (in vitro) (Fig. 1). There has been observed a gradient of glucose incorporation into bovine cumulus layers, with glucose taken up by cells on the outer layers and then, through both facilitated transport and diffusion, progressed inwards to the corona radiate and oocyte by the gap junctions [10]. Due to high phosphofructokinase activity, cumulus cells convert glucose to pyruvate, lactate or NADPH, which are further transferred to oocytes [10]. Pyruvate and lactate are then metabolized via the tricarboxylic pathway (TCA) followed by oxidative phosphorylation to energy essential for oocyte development. The oocyte in turn ensures its own delivery of pyruvate by up-regulating glycolytic genes in murine cumulus cells [11]. The up-regulation of glycolysis is curried by paracrine factors secreted by oocyte and it depends on the developmental stage of the oocyte, since only fully grown oocyte has this capacity [11]. Removing murine oocytes from cumulus-oocyte complexes reduces the level of transcripts encoding glycolytic enzymes ( $P f k p, L d h a$ ) in cumulus cells and this process may be completely reversed by co-culturing cumulus cells with fully grown oocytes [11]. This observation indicates that the experiments focused on energy production in the oocyte cannot be limited to this single cell exclusively but it should range also cumulus cells. Pyruvate, except of the direct transport to the oocyte, may also be secreted by the cumulus cells and collected from the surrounding medium by the oocyte [12].

Cumulus cells metabolize glucose through four pathways: glycolysis, pentose phosphate, hexoxamine and polyol [10]. Anaerobic glycolysis is a major pathway for glucose metabolism in the mam- malian ovarian follicles [13]. It is beneficial for mtDNA synthesis, as it avoids overloading the immature mitochondria for Krebs cycle metabolism, which could lead to oxidative stress [14]. Both glycolysis and PPP seem to be the same important, since they affect nuclear and cytoplasmic maturation of oocytes of several species (e.g. mouse - [15], pig - [16], cow - [17]). These factors have been shown to play key roles in developmental competence of cow [17] or pig [18] oocytes.

Pentose phosphate pathway, although crucial for many processes described above, is minor for glucose and it is species specific. As described for mouse oocytes, it metabolizes less than 3\% [19], whereas bovine oocytes reveal higher PPP activity when compared to cumulus cells [9]. PPP pathway does not generate ATP, however due to the production of NADPH, it is crucial for cytoplasmic integrity and redox state through the reduction of glutathione to $\mathrm{GSH}[10,20]$. Additionally this process leads to synthesis of ribose-5-phosphate that is critical for DNA and RNA synthesis [10]. It has been proposed for mice and cattle that PPP is involved in the progression of all stages of meiosis, MI-MII transition and the resumption of meiosis after fertilisation via production of NADPH followed by generation of ROS essential for signalling pathway [21, 22]. Also pig oocytes reveal GVBD to MII transition dependent on PPP pathway activity [18]. There was observed an effect of PPP inhibition on glucose uptake and lactate production, which suggests an inhibitory effect on glycolytic activity [23].

Hexosamine biosynthesis pathway provides substrate for hyaluronic acid production for extracellular matrix expansion and O-linked protein glycosylation for cell signalling and fuel sensing [10]. It has been observed that increased glucose consumption by COCs during the final stages of IVM is to generate matrix via the hexosamine biosynthesis pathway [24]. After FSH supplementation of the bovine IVM medium, an increase in the consumption of glucose via hexosamine pathway was observed [21].

The minor polyol pathway produces fructose and sorbitol in hyperglycemic conditions, resulting in negative consequences for oocyte quality [10]. Under standard glycaemic conditions, the polyol pathway accounts for very little of total glucose metabolism.

With the progression of bovine COC maturation, increase of consumption of glucose, pyruvate and oxygen is observed [8], which indicates the increasing demand for energy. However there is a limiting level of glucose in the maturation medium, which supports the proper oocyte development. Studies showed that in vitro maturation of bovine oocytes in sub-optimal concentrations of glucose resulted in delayed meiotic maturation, fertilization and embryonic development [10]. The average concentration of glucose in the follicular fluid is comparable to the one observed in plasma, but it is species specific. For cattle it ranges between 1.4 and $5 \mathrm{mM}$ [21], sheep 1.2 to $1.7 \mathrm{mM}$ [25] or mouse 0.01 to $2.4 \mathrm{mM}$ [26]. Since in vivo conditions may reveal quite dynamic changes in glucose level depending on mother-originating stimuli, in vitro maturation is conducted in stable medium with precisely defined composition. It was shown that the optimal glucose concentration in the maturation medium for cattle ranges from 2.3 to $10 \mathrm{mM}$, and any higher or lower concentrations are detrimental to oocyte development [10]. Surprisingly, even a short (1 h) exposure of murine COCs to media containing unphysiological concentration of glucose can have a negative effect on embryo development [27]. 


\section{LIPIDS METABOLISM}

\section{GLUCOSE METABOLISM}
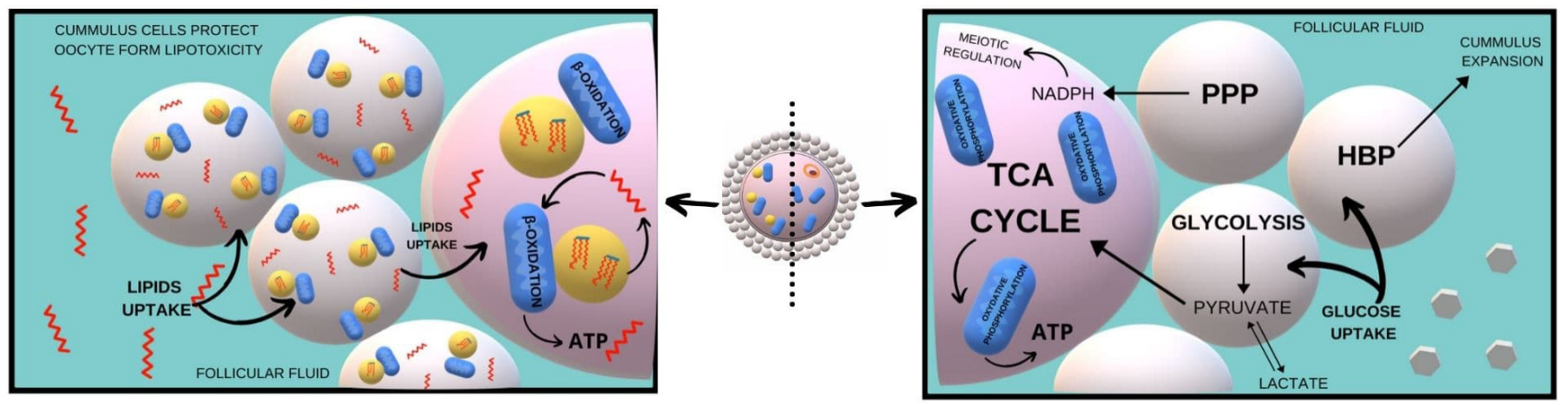

Fig. 1. A diagram of mechanisms of lipids and glucose metabolism within the cumulus oocyte complex. The left part of the diagram shows lipids metabolism, whereas the right part is focused on glucose metabolism. In both pathways, a crucial role play cumulus cells, which collect lipids and glucose from follicular fluid, protect oocyte from lipotoxicity (lipids metabolism) or convert glucose to pyruvate (glucose metabolism). The final product of either lipids or glucose metabolism is ATP.

\begin{tabular}{|c|c|c|}
\hline & $\begin{array}{c}\text { METABOLISM } \\
\text { MODIFICATIONS }\end{array}$ & LIPIDS/GLUCOSE METABOLISM INTERACTIONS \\
\hline 1. & $\begin{array}{c}\text { + high NEFA suppl. } \\
\text { (cattle) } \\
{[51,52]}\end{array}$ & $\begin{array}{l}\text { (20) GLUCOSE ANo LACtate MEtabolsM } \\
\text { Ros ACUMULATION }\end{array}$ \\
\hline 2. & $\begin{array}{l}\text { + high NEFA suppl. } \\
+ \text { high glucose suppl. } \\
\text { (cattle) [51] }\end{array}$ & $\begin{array}{l}\text { (B) GLUCOSE CONSUMPtion } \\
\text { w LACTATE PRODUCtion }\end{array}$ \\
\hline 3. & $\begin{array}{l}\text { + high NEFA suppl. } \\
+ \text { low glucose suppl. } \\
\text { (cattle) [51] }\end{array}$ & $\begin{array}{l}\text { y GLUCOSE CONSUMPTION } \\
\text { y LACTATE PRODUCTION }\end{array}$ \\
\hline 4. & $\begin{array}{c}\text { Fatty acids oxidation } \\
\text { induction (mouse) } \\
\text { [54] }\end{array}$ & $\begin{array}{l}\text { Y LIPID CONTENT } \\
\text { \ GLUCOSE CONSUMPTION }\end{array}$ \\
\hline 5. & $\begin{array}{c}\text { Fatty acids oxidation } \\
\text { inhibition (mouse) } \\
{[45,54]}\end{array}$ & $\begin{array}{l}\text { (2) GLUCOSE CONSUMPTION } \\
\text { w MRNA OF GLUCOSE TRANSPORTER } 1 \\
\text { I LIPID CONTENT } \\
\text { w mRNA OF GLUCOSE TRANSPORTER } 1\end{array}$ \\
\hline 6. & $\begin{array}{c}\text { Fatty acids oxidation } \\
\text { inhibition (pig) } \\
\text { [45] }\end{array}$ & GLUCOSE CONSUMPTION \\
\hline 7. & $\begin{array}{c}\text { Fatty acids oxidation } \\
\text { inhibition (cattle) } \\
\text { [45] }\end{array}$ & GLUCOSE CONSUMPTION \\
\hline 8. & & 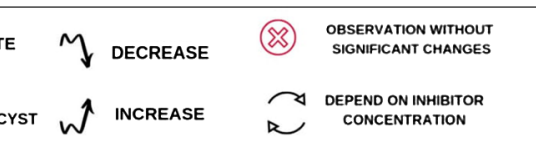 \\
\hline
\end{tabular}

Fig. 2. A chart summarizing described in the literature interactions between lipids and glucose metabolism after modifications of cumulus-oocyte complexes (COCs) maturation environment. Lines 1 to 3 - maturation media are supplemented with non-estrified fatty acids (NEFA) or glucose in concentrations higher or lower than physiological. Line 4 - fatty acid oxidation is induced via supplementation of maturation media with carnitine. Lines 5 to 7 - fatty acid oxidation is inhibited via supplementation of maturation media with etomoxir. Variable effects of the described in vitro maturation (IVM) modifications within the oocyte, cumulus cells or blastocysts are summarized. The legend of the graphic signs used in the chart is present in the line 8 . 


\section{Fatty Acid Metabolism within the Follicular Environment}

Fatty acids show very high energetic value, giving 5-6 times more ATP product when compared to glucose. Within the follicular environment, fatty acids are observed in oocyte, cumulus cells, other follicular cells as well as in follicular fluid [28]. In follicular fluid of heifers, 37 fatty acids are present with the total concentration of $600 \mu \mathrm{g} / \mathrm{ml}$. The highest concentration reveal: oleic acid $(87 \mu \mathrm{g} /$ $\mathrm{ml})$, linoleic acid $(48 \mu \mathrm{g} / \mathrm{ml})$, stearic acid $(31 \mu \mathrm{g} / \mathrm{ml})$ and palmitic acid $(26 \mu \mathrm{g} / \mathrm{ml})$ [29]. With regard to follicular fluid of prepubertal gilts, total concentration of fatty acids is $890 \mu \mathrm{g} / \mathrm{ml}$ and the most abundant particular fatty acids are: palmitic acid $(232 \mu \mathrm{g} / \mathrm{ml})$, oleic acid $(203 \mu \mathrm{g} / \mathrm{ml})$, linoleic acid $(190 \mu \mathrm{g} / \mathrm{ml})$ and stearic acid $(142$ $\mu \mathrm{g} / \mathrm{ml})$. The concentration of selected fatty acids depend on many factors e.g. female reproductive status [29, 30], size of follicle [29] or year season [31].

In oocytes lipids are stored as triacylglyceroles (fatty acids estrified to glycerol) in lipid droplets, whereas free fatty acids may be localized also within the cytoplasm (Fig. 1). Lipid droplets together with mitochondria create so called "metabolic units". Free fatty acids obtained from triacylglyceroles can be directly transported from lipid droplets to mitochondria and oxidized via $\beta$-oxidation, which reveals a fast and direct way of energy acquisition [32, 33]. As the ovarian follicle grows, the number of lipid droplets associated with endoplasmic reticulum and mitochondria increase, denoting a rise in oocyte metabolism (rev. [34]). During the transformation from primary to secondary follicle, lipid droplets change from small round dark droplets to large gray structures in pigs, which reflects a change in fatty acids composition [35]. These changes may be species specific and related to such factors as physiological status of the animal or its diet $[36,37]$. During the antrum formation in the follicle, large amounts of lipids are observed within the oocyte. It may suggest the importance of energy metabolism during oocyte growth, which also indicates the demand for energy accumulation for the meiosis resumption and oocyte maturation, which in most mammalian species take place shortly before ovulation. The process of oocyte maturation significantly affects the lipid droplets within the whole cumulus-oocyte complex. In bovine oocytes there is observed the increase of lipid droplets number after IVM [38, 39]. Interestingly, changes of lipid droplets number during oocyte maturation depends on e.g. the reproductive status of the female, which has been confirmed in cattle [38] and pigs [40]. In bovine oocytes of prepubertal heifers there is observed lower number of lipid droplets when compared to mature cows [38]. In contrary, significantly lower number of lipid droplets is present in oocytes originating from cyclic pigs when compared to prepubertal [40]. The observed differences are difficult to explain, since these two species show different requirements for the lipid metabolism. Besides cow oocytes contain rather higher number of smaller lipid droplets, whereas porcine oocytes lower number of bigger lipid droplets. Therefore it is suggested that maybe total lipid content or total lipid droplets area characterise lipid droplets better than droplets number itself.

Although studies show that glucose or pyruvate are essential for successful oocyte maturation, fatty acid $\beta$-oxidation is also an important source of energy during oocyte maturation. It may be suggested that fatty acid oxidation (FAO) is especially important during oocyte maturation, since until that moment the amount of lipid storage within the oocyte increases and the maturation process itself is very energy consuming, decreasing the number of lipid droplets $[38,39]$. Mammalian immature oocytes contain endogenous lipid reserve but its amount varies among species (e.g. $63 \mathrm{ng}$ in the cow vs. $161 \mathrm{ng}$ in the pig, [41]). Trigliceride (uncharged ester of glycerol) is the main lipid found in mammalian oocytes, however its level also depends on species (30\% in the sheep, $35 \%$ in the cow and $60 \%$ in the pig oocyte; [42]). Oocyte maturation is accompanied by fatty acid synthesis, lipolysis activity and FAO both in oocytes and cumulus cells and these processes influence meiosis progression. It was proved by inhibition of FAO in both cumulus enclosed oocytes and denuded oocytes, where it resulted in the reduction of maturation rate [43]. Delayed meiosis resumption after FAO inhibition has also been reported in mice $[33,44]$.

What is interesting, between species there are different reactions of COCs on the inhibition of lipid metabolism during IVM, depending on the amount of lipids accumulated in the oocyte's cytoplasm. Mouse COCs, which represent low amount of accumulated lipids, needed higher amount of etomoxir $(250 \mu \mathrm{M})$ to show similar effect as in cattle, suggesting that FAO may not play as important role during mouse oocyte maturation. By contrast, porcine oocytes with high intracellular lipid content, arrested during maturation even after exposure to low concentrations of etomoxir $(10 \mu \mathrm{M})$. Therefore, in these COCs probably FAO is essential for proper maturation [45].

Crucial elements of lipid metabolism pathways in the oocyte are cumulus cells, which tightly surround the oocyte. It was shown that bovine cumulus cells protect the oocyte from toxic effect of fatty acids accumulated in the maturation environment $[4,5]$. Short exposure time to elevated levels of free fatty acids does not harm the oocyte, due to the accumulation of fatty acids in the cumulus cells. This protective effect is visible even during further uninterrupted embryo development. Cumulus cells are able to protect the oocyte and the nascent embryo probably due to the activity of stearoyl-CoA desaturase, which converts saturated into monounsaturated fatty acids [46]. Bovine oocytes that were denuded before maturation had decreased developmental competence and had significantly less lipid content than cumulus enclosed oocytes [47]. It suggests that cumulus cells help to regulate the accumulation and metabolism of intracellular lipids during oocyte maturation and protect the oocyte from those fatty acids which affect negatively on oocyte competence $[4,5]$. Studies show that inhibition of FAO during bovine IVM significantly decrease lipid droplets number in cumulus cells as well as the percentage of cumulus cells with visible lipid droplets when compared to standard IVM procedure [43]. Authors also suggest that FAO inhibition conditions limit the capacity to metabolize lipids and therefore it may cause cumulus cell death, which strongly affects oocyte quality[43]. Besides, any disturbances in lipid homeostasis observed in cumulus cells may also negatively influence oocyte development, since during IVM there are observed massive changes in lipid profiles in cumulus cells. What is interesting, some lipid species abundances increase, whereas other decrease, which indicates the demand for the homeostasis in energy metabolism of the oocyte as well as cumulus cells [43]. 


\section{The Impact of Energy Metabolism Modifications during Oocyte Maturation on Embryo Development}

Many previous studies showed that oocyte maturation conditions affect embryo development (rev. [48]). The question arises, whether energy metabolism changes during the process of oocyte development and maturation are important for embryo quality and quantity. Already in 1992 Britt hypothesized that reduced fertility in cows after negative energy balance may arise from an effect of the oocytes exposure to metabolic stress during early stages of follicular development [49]. Therefore imbalanced energy metabolism seems to be crucial for this phenomenon.

In cattle, when NEFA was added to IVM medium, cleavage rate was not affected, however the blastocyst rate was decreased [50]. This result was not confirmed by the studies of De Bie et al. [51], who has not observed any changes in both cleavage and blastocyst rate. However both manuscripts describe no impact of NEFA supplementation during IVM on blastocyst quality, revealed by total cell number $[50,51]$, ICM and TE cell number [50, 51] or apoptotic index [50]. Therefore detrimental lipid conditions of oocyte maturation reduce the chance to develop to the blastocyst stage, but the embryos that do develop, are of good quality. De Bie et al. [51] additionally observed lower cleavage and blastocyst rate when NEFA were added together with low or high glucose concentration but again the quality of blastocysts was unchanged. This means that some embryos may compensate unfavourable maturation conditions, however the mechanism of overcoming these disadvantages is unknown. There was a significant effect of bovine embryo development when oocyte maturation was performed in the presence of selected fatty acids [52]. Supplementation by steric acid did not change cleavage and blastocyst rate but it decreased blastocyst's cell number and apoptotic cell ratio. In contrary, supplementation with high concentrations of palmitic and oleic acids resulted in lower blastocyst rate and higher apoptotic index but it did not affected blastocyst's cell number. Therefore, NEFA-exposure during maturation may have a negative impact on post-genome activated development, however it is observed only with regard to some fatty acids. The compensate effect of oleic acid for negative effect of saturated palmitic and stearic acids in cattle has been previously described [39]. Besides there was observed an important protective effect of cumulus cells, which accumulates the excess of toxic fatty acids and promotes further proper embryo development [4]. However when combination of several fatty acids (palmitic, stearic and oleic) were added to the maturation medium, massive changes in the blastocysts gene expression were observed, with the highest contribution of genes involved in lipid metabolism (storage) [53]. According to authors it is unresolved whether it provides protective and/or compensatory mechanisms rather than activating other toxic-related pathways.

For the mouse embryos, stimulation of FAO during in vitro maturation of oocytes increases embryonic development but does not alter embryo quality. In contrary, when FAO is inhibited, it decreases mice embryo development (both cleavage and blastocyst rate). It also reduces total cell number and trophoectoderm cell number-indicators of blastocyst potential [54]. Basing on the results of other species, it is suggested that there is an optimal range of intracellular lipids that is compatible with high oocyte quality and it further affects embryo development capacity. Good quality bovine oocytes have higher levels of intracellular lipids, which appears optimal for this species, as oocytes with low lipid content have reduced developmental potential [55]. It is also suggested that lipid content of oocytes reflects a balance in the activity of multiple metabolic pathways necessary to successfully support future embryo development.

Studies show that modifications of glucose metabolism during in vitro maturation also have an effect on embryo developmental potential, however this phenomenon is definitely less described. The supplementation of maturation medium with NADP, which stimulated glucose uptake via increase of PPP pathway, did not change cleavage rate however it significantly decreased blastocyst rate of bovine embryos [23]. Authors suggest that the negative effect on embryo development is caused by disturbed mitochondrial migration during early cleavages.

\section{Homeostasis between Glucose and Fatty acid Metabolism and Its Impact on Gamete Potential}

Glucose consumption and fatty acid metabolism seem to be correlate in mouse COC [54] as well as in bovine embryos [52]. Several experiments that describe the relations between those metabolic pathways are summarized in Fig. 2. A provision of NEFA during in vitro maturation of bovine oocytes resulted in decrease of glucose uptake in the blastocysts, which has been explained as a promotion of fatty acid oxidation over glucose oxidation [52]. Surprisingly higher mRNA level of glucose transporter 1 was also observed but probably the final production of the protein has been interrupted. Paczkowski et al. [54] showed that stimulation of fatty acid oxidation (via carnitine supplementation to medium) during IVM reduced intracellular lipid content in the mice oocyte, which indicates increased utilization of intracellular fatty acid stores. In the same experiment also reduction of glucose consumption was observed. In contrary, when FAO was blocked via etomoxir inhibition, higher mRNA level of glucose transporter 1 (Slc2a1) was detected both in oocytes and cumulus cells. Also glucose consumption from the IVM medium was increased when compared to the medium supplemented with carnitine. This clearly demonstrates the existence of a balance between the metabolism of glucose and fatty acids within the COC. The same authors in other publication show however that energy metabolism changes may differ, depending on the analysed species [45]. Mice COCs reveal no changes of glucose consumption after inhibition of FAO during IVM. Bovine COCs show either increase or decrease of glucose consumption, depending on the concentration of inhibitory factor (etomoxir). With regard to porcine COCs, no significant change of glucose consumption is observed. Authors hypothesize that in bovine COCs glucose consumption increases when COCs are exposed to etomoxir to compensate for reduced ATP production and allow meiosis to continue. In contrary, etomoxir supplementation during maturation of porcine COCs did not change the consumption of glucose, therefore these cells were not able to change the energetic metabolism into the pathways of glucose consumption available at the moment, which was observed in bovine COCs. Basing on these findings, together with the data on expression of glycolysis controlling genes in cumulus cells, authors suggest that porcine oocytes are very sensitive to FAO perturbations. Utilisation of glucose as an alternative 
energy source may be observed only in cumulus cells metabolism.

In the study of De Bie et al. [51], NEFA supplementation during IVM did not affect bovine COC glucose and lactate metabolism as well as reactive oxygen species (ROS) accumulation in the oocytes. When high level of NEFA was combined with high glucose concentration, glucose consumption was also not altered, but on the contrary lactate production was significantly increased. This increase of lactate/2 to glucose ratio indicates that the majority of glucose consumed was used in anaerobic glycolysis yielding lactate, which is suggested to be present in oocytes and early embryos as well as other rapid proliferating cells. This alternative form of metabolism was called Warburg effect [56]. It directs pyruvate away from the TCA cycle and metabolizes to lactate. This conversion produces NAD+ but it is less efficient when compared to standard aerobic metabolism (only 2 moles of ATP produced from 1 mole of glucose). Interestingly, cells continue this less efficient method of ATP production from glucose, even when oxygen levels are adequate and mitochondria remain functional. This phenomenon is explained by probable other metabolic requirements beyond ATP production from glucose. However, it is underlined that other alternative sources of energy production, such as fatty acids, must be available to support basal TCA activity and ATP production [57]. This confirms the crucial role of glucose/fatty acids balance in the oocyte/embryo proper development.

Oocyte maturation in media supplemented with high level of fatty acids together with low glucose concentration gave lower glucose consumption and lactate production when compared to maturation with high fatty acid (FA) level and high glucose concentration [51]. Despite low glucose consumption, lactate/ 2 to glucose ratio was similar in both of the experimental groups. It indicates that when glucose availability is reduced, it is stored for other crucial pathways (e.g. PPP for nucleic acid synthesis and REDOX regulation) and FA oxidation becomes preferable source of energy. However Sutton-McDowall et al. [10] suggested that NEFA cannot support oocyte development without glucose supply as they are not able to provide nucleic acid precursors or defend against oxygen species.

\section{Conclusions}

There are species-specific energy requirements for oocytes, and most probably these processes depend on the amount of energy substrates collected within the cell. Although glucose is usually more preferable source of energy for COCs, fatty acid oxidation is also essential to oocyte growth and maturation. The amount of lipids present in the ooplasm affect the sensitivity to FAO inhibition. Therefore it is suggested that a proper concentration of lipids in the ooplasm as well as glucose in the maturation environment [follicular fluid or in vitro maturation (IVM) medium] are necessary for proper oocyte developmental competence. Also homeostasis between fatty acids and glucose metabolism pathways is underlined with regard to balanced oocyte growth and maturation.

There is observed an importance of cumulus cells in the processes of energy production by the oocyte, both when glucose or fatty acids metabolism are discussed. With regard to glucose metabolism, cumulus cells support the oocyte via conversion the glucose to pyruvate. When lipid metabolism is discussed, cumulus cells act as protectors from the negative impact of some fatty acids and accumulate them in lipid droplets.

What is the most interesting, an impact of energy metabolism modifications during oocyte growth and maturation on the embryo development has been widely described in the studies [50-53]. Therefore further experiments are important to reveal the influence of follicular (maternal) environment on the gamete and embryo quality.

\section{Acknowledgements}

Funding: National Science Centre, Poland, project no 2017/27/B/ NZ9/00904.

\section{References}

1. Randle PJ. Regulatory interactions between lipids and carbohydrates: the glucose fatty acid cycle after 35 years. Diabetes Metab Rev 1998; 14: 263-283. [Medline] [CrossRef]

2. Dumesic DA, Meldrum DR, Katz-Jaffe MG, Krisher RL, Schooleraft WB. Oocyte environment: follicular fluid and cumulus cells are critical for oocyte health. Fertil Steril 2015; 103: 303-316. [Medline] [CrossRef]

3. Leroy JL, Valckx SD, Jordaens L, De Bie J, Desmet KL, Van Hoeck V, Britt JH, Marei WF, Bols PE. Nutrition and maternal metabolic health in relation to oocyte and embryo quality: critical views on what we learned from the dairy cow model. Reprod Fertil Dev 2015; 27: 693-703. [Medline] [CrossRef]

4. Aardema H, Lolicato F, van de Lest CH, Brouwers JF, Vaandrager AB, van Tol HT, Roelen BA, Vos PL, Helms JB, Gadella BM. Bovine cumulus cells protect maturing oocytes from increased fatty acid levels by massive intracellular lipid storage. Biol Reprod 2013; 88: 164. [Medline] [CrossRef]

5. Lolicato F, Brouwers JF, de Lest CH, Wubbolts R, Aardema H, Priore P, Roelen BA, Helms JB, Gadella BM. The cumulus cell layer protects the bovine maturing oocyte against fatty acid-induced lipotoxicity. Biol Reprod 2015; 92: 16. [Medline] [CrossRef]

6. Moore SG, Fair T, Lonergan P, Butler ST. Genetic merit for fertility traits in Holstein cows: IV. Transition period, uterine health, and resumption of cyclicity. J Dairy Sci 2014; 97: 2740-2752. [Medline] [CrossRef]

7. Warzych E, Cieslak A, Madeja ZE, Pawlak P, Wolc A, Lechniak D. Multifactorial analysis of the follicular environment is predictive of oocyte morphology in cattle. $J$ Reprod Dev 2014; 60: 1-8. [Medline] [CrossRef]

8. Sutton ML, Cetica PD, Beconi MT, Kind KL, Gilchrist RB, Thompson JG. Influence of oocyte-secreted factors and culture duration on the metabolic activity of bovine cumulus cell complexes. Reproduction 2003; 126: 27-34. [Medline] [CrossRef]

9. Cetica P, Pintos L, Dalvit G, Beconi M. Activity of key enzymes involved in glucose and triglyceride catabolism during bovine oocyte maturation in vitro. Reproduction 2002; 124: 675-681. [Medline] [CrossRef]

10. Sutton-McDowall ML, Gilchrist RB, Thompson JG. The pivotal role of glucose metabolism in determining oocyte developmental competence. Reproduction 2010; 139: 685-695. [Medline] [CrossRef]

11. Sugiura K, Pendola FL, Eppig JJ. Oocyte control of metabolic cooperativity between oocytes and companion granulosa cells: energy metabolism. Dev Biol 2005; 279: 20-30. [Medline] [CrossRef]

12. Su YQ, Sugiura K, Eppig JJ. Mouse oocyte control of granulosa cell development and function: paracrine regulation of cumulus cell metabolism. Semin Reprod Med 2009; 27 : 32-42. [Medline] [CrossRef]

13. Downs SM, Utecht AM. Metabolism of radiolabeled glucose by mouse oocytes and oocyte-cumulus cell complexes. Biol Reprod 1999; 60: 1446-1452. [Medline] [CrossRef]

14. Bermejo-Alvarez P, Lonergan P, Rizos D, Gutiérrez-Adan A. Low oxygen tension during IVM improves bovine oocyte competence and enhances anaerobic glycolysis. Reprod Biomed Online 2010; 20: 341-349. [Medline] [CrossRef]

15. Downs SM. The influence of glucose, cumulus cells, and metabolic coupling on ATP levels and meiotic control in the isolated mouse oocyte. Dev Biol 1995; 167: 502-512. [Medline] [CrossRef]

16. Krisher RL, Brad AM, Herrick JR, Sparman ML, Swain JE. A comparative analysis of metabolism and viability in porcine oocytes during in vitro maturation. Anim Reprod Sci 2007; 98: 72-96. [Medline] [CrossRef]

17. Steeves TE, Gardner DK. Temporal and differential effects of amino acids on bovine embryo development in culture. Biol Reprod 1999; 61: 731-740. [Medline] [CrossRef]

18. Herrick JR, Brad AM, Krisher RL. Chemical manipulation of glucose metabolism in porcine oocytes: effects on nuclear and cytoplasmic maturation in vitro. Reproduction 2006; 131: 289-298. [Medline] [CrossRef] 
19. Urner F, Sakkas D. Characterization of glycolysis and pentose phosphate pathway activity during sperm entry into the mouse oocyte. Biol Reprod 1999; 60: 973-978. [Medline] [CrossRef]

20. Tian WN, Braunstein LD, Pang J, Stuhlmeier KM, Xi QC, Tian X, Stanton RC. Importance of glucose-6-phosphate dehydrogenase activity for cell growth. $J$ Biol Chem 1998; 273: 10609-10617. [Medline] [CrossRef]

21. Sutton-McDowall ML, Gilchrist RB, Thompson JG. Effect of hexoses and gonadotrophin supplementation on bovine oocyte nuclear maturation during in vitro maturation in a synthetic follicle fluid medium. Reprod Fertil Dev 2005; 17: 407-415. [Medline] [CrossRef]

22. Urner F, Sakkas D. Involvement of the pentose phosphate pathway and redox regulation in fertilization in the mouse. Mol Reprod Dev 2005; 70: 494-503. [Medline] [CrossRef]

23. Gutnisky C, Dalvit GC, Thompson JG, Cetica PD. Pentose phosphate pathway activity: effect on in vitro maturation and oxidative status of bovine oocytes. Reprod Fertil Dev 2014; 26: 931-942. [Medline] [CrossRef]

24. Gutnisky C, Dalvit GC, Pintos LN, Thompson JG, Beconi MT, Cetica PD. Influence of hyaluronic acid synthesis and cumulus mucification on bovine oocyte in vitro maturation, fertilisation and embryo development. Reprod Fertil Dev 2007; 19: 488-497. [Medline] [CrossRef]

25. Nandi S, Girish Kumar V, Manjunatha BM, Ramesh HS, Gupta PS. Follicular fluid concentrations of glucose, lactate and pyruvate in buffalo and sheep, and their effects on cultured oocytes, granulosa and cumulus cells. Theriogenology 2008; 69: 186-196. [Medline] [CrossRef]

26. Harris SE, Gopichandran N, Picton HM, Leese HJ, Orsi NM. Nutrient concentrations in murine follicular fluid and the female reproductive tract. Theriogenology 2005; 64: 992-1006. [Medline] [CrossRef]

27. Frank LA, Sutton-McDowall ML, Russell DL, Wang X, Feil DK, Gilchrist RB, Thompson JG. Effect of varying glucose and glucosamine concentration in vitro on mouse oocyte maturation and developmental competence. Reprod Fertil Dev 2013; 25: 1095-1104. [Medline] [CrossRef]

28. Bertevello PS, Teixeira-Gomes AP, Seyer A, Vitorino Carvalho A, Labas V, Blache MC, Banliat C, Cordeiro LAV, Duranthon V, Papillier P, Maillard V, Elis S, Uzbekova $\mathbf{S}$. Lipid identification and transcriptional analysis of controlling enzymes in bovine ovarian follicle. Int J Mol Sci 2018; 19: 19. [Medline] [CrossRef]

29. Bender K, Walsh S, Evans AC, Fair T, Brennan L. Metabolite concentrations in follicular fluid may explain differences in fertility between heifers and lactating cows. Reproduction 2010; 139: 1047-1055. [Medline] [CrossRef]

30. Pawlak P, Cieslak A, Warzych E, Zejden Z, Szumacher-Strabel M, Molinska-Glura M, Lechniak D. No single way to explain cytoplasmic maturation of oocytes from prepubertal and cyclic gilts. Theriogenology 2012; 78: 2020-2030. [Medline] [CrossRef]

31. Zeron Y, Ocheretny A, Kedar O, Borochov A, Sklan D, Arav A. Seasonal changes in bovine fertility: relation to developmental competence of oocytes, membrane properties and fatty acid composition of follicles. Reproduction 2001; 121: 447-454. [Medline] [CrossRef]

32. Sturmey RG, O'Toole PJ, Leese HJ. Fluorescence resonance energy transfer analysis of mitochondrial:lipid association in the porcine oocyte. Reproduction 2006; 132: 829-837. [Medline] [CrossRef]

33. Dunning KR, Cashman K, Russell DL, Thompson JG, Norman RJ, Robker RL. Beta-oxidation is essential for mouse oocyte developmental competence and early embryo development. Biol Reprod 2010; 83: 909-918. [Medline] [CrossRef]

34. Paulini F, Silva RC, Rôlo JL, Lucci CM. Ultrastructural changes in oocytes during folliculogenesis in domestic mammals. J Ovarian Res 2014; 7: 102. [Medline] [CrossRef]

35. Silva RC, Báo SN, Jivago JL, Lucci CM. Ultrastructural characterization of porcine oocytes and adjacent follicular cells during follicle development: lipid component evolution. Theriogenology 2011; 76: 1647-1657. [Medline] [CrossRef]

36. Adamiak SJ, Mackie K, Watt RG, Webb R, Sinclair KD. Impact of nutrition on oocyte quality: cumulative effects of body composition and diet leading to hyperinsulinemia in cattle. Biol Reprod 2005; 73: 918-926. [Medline] [CrossRef]

37. Leroy JL, Vanholder T, Delanghe JR, Opsomer G, Van Soom A, Bols PE, de Kruif A. Metabolite and ionic composition of follicular fluid from different-sized follicles and their relationship to serum concentrations in dairy cows. Anim Reprod Sci 2004; 80: 201-211. [Medline] [CrossRef]

38. Warzych E, Pawlak P, Pszczola M, Cieslak A, Lechniak D. Prepubertal heifers versus cows-The differences in the follicular environment. Theriogenology 2017; 87: 36-47.
[Medline] [CrossRef]

39. Aardema H, Vos PL, Lolicato F, Roelen BA, Knijn HM, Vaandrager AB, Helms JB, Gadella BM. Oleic acid prevents detrimental effects of saturated fatty acids on bovine oocyte developmental competence. Biol Reprod 2011; 85: 62-69. [Medline] [CrossRef]

40. Pawlak P, Warzych E, Cieslak A, Malyszka N, Maciejewska E, Madeja ZE, Lechniak D. The consequences of porcine IVM medium supplementation with follicular fluid become reflected in embryo quality, yield and gene expression patterns. Sci Rep 2018; 8 15306. [Medline] [CrossRef]

41. McEvoy TG, Coull GD, Broadbent PJ, Hutchinson JS, Speake BK. Fatty acid composition of lipids in immature cattle, pig and sheep oocytes with intact zona pellucida. $J$ Reprod Fertil 2000; 118: 163-170. [Medline] [CrossRef]

42. Sturmey RG, Reis A, Leese HJ, McEvoy TG. Role of fatty acids in energy provision during oocyte maturation and early embryo development. Reprod Domest Anim 2009; 44(Suppl 3): 50-58. [Medline] [CrossRef]

43. Sanchez-Lazo L, Brisard D, Elis S, Maillard V, Uzbekov R, Labas V, Desmarchais A, Papillier P, Monget P, Uzbekova S. Fatty acid synthesis and oxidation in cumulus cells support oocyte maturation in bovine. Mol Endocrinol 2014; 28: 1502-1521. [Medline] [CrossRef]

44. Downs SM, Mosey JL, Klinger J. Fatty acid oxidation and meiotic resumption in mouse oocytes. Mol Reprod Dev 2009; 76: 844-853. [Medline] [CrossRef]

45. Paczkowski M, Silva E, Schoolcraft WB, Krisher RL. Comparative importance of fatty acid beta-oxidation to nuclear maturation, gene expression, and glucose metabolism in mouse, bovine, and porcine cumulus oocyte complexes. Biol Reprod 2013; 88: 111 [Medline] [CrossRef]

46. Aardema H, van Tol HTA, Wubbolts RW, Brouwers JFHM, Gadella BM, Roelen BAJ. Stearoyl-CoA desaturase activity in bovine cumulus cells protects the oocyte against saturated fatty acid stress. Biol Reprod 2017; 96: 982-992. [Medline] [CrossRef]

47. Auclair S, Uzbekov R, Elis S, Sanchez L, Kireev I, Lardic L, Dalbies-Tran R, Uz bekova $\mathrm{S}$. Absence of cumulus cells during in vitro maturation affects lipid metabolism in bovine oocytes. Am J Physiol Endocrinol Metab 2013; 304: E599-E613. [Medline] [CrossRef]

48. Lonergan P, Fair T. Maturation of Oocytes in Vitro. Annu Rev Anim Biosci 2016; 4 255-268. [Medline] [CrossRef]

49. Britt JH. Impact of early postpartum metabolism on follicular development and fertility The Bovine Proceedings 1992; 24: 39-43.

50. Sutton-McDowall ML, Wu LL, Purdey M, Abell AD, Goldys EM, MacMillan KL, Thompson JG, Robker RL. Nonesterified fatty acid-induced endoplasmic reticulum stress in cattle cumulus oocyte complexes alters cell metabolism and developmental competence. Biol Reprod 2016; 94: 23. [Medline] [CrossRef]

51. De Bie J, Marei WFA, Maillo V, Jordaens L, Gutierrez-Adan A, Bols PEJ, Leroy JLMR. Differential effects of high and low glucose concentrations during lipolysis-like conditions on bovine in vitro oocyte quality, metabolism and subsequent embryo development. Reprod Fertil Dev 2017; 29: 2284-2300. [Medline] [CrossRef]

52. Van Hoeck V, Sturmey RG, Bermejo-Alvarez P, Rizos D, Gutierrez-Adan A, Leese HJ, Bols PE, Leroy JL. Elevated non-esterified fatty acid concentrations during bovine oocyte maturation compromise early embryo physiology. PLoS One 2011; 6: e23183. [Medline] [CrossRef]

53. Van Hoeck V, Rizos D, Gutierrez-Adan A, Pintelon I, Jorssen E, Dufort I, Sirard MA, Verlaet A, Hermans N, Bols PE, Leroy JL. Interaction between differential gen expression profile and phenotype in bovine blastocysts originating from oocytes exposed to elevated non-esterified fatty acid concentrations. Reprod Fertil Dev 2015; 27: 372-384. [Medline] [CrossRef]

54. Paczkowski M, Schoolcraft WB, Krisher RL. Fatty acid metabolism during maturation affects glucose uptake and is essential to oocyte competence. Reproduction 2014; 148: 429-439. [Medline] [CrossRef]

55. Jeong WJ, Cho SJ, Lee HS, Deb GK, Lee YS, Kwon TH, Kong IK. Effect of cytoplasmic lipid content on in vitro developmental efficiency of bovine IVP embryos. Theriogenology 2009; 72: 584-589. [Medline] [CrossRef]

56. Warburg O. On the origin of cancer cells. Science 1956; 123: 309-314. [Medline] [CrossRef]

57. Krisher RL, Prather RS. A role for the Warburg effect in preimplantation embryo development: metabolic modification to support rapid cell proliferation. Mol Reprod Dev 2012 79: 311-320. [Medline] [CrossRef] 